\title{
A Study on the Present Situation and Countermeasures of Xinjiang Modern Grassroots Culture Transmission
}

\author{
Ma Xiaoling \\ College of Language and Literature \\ Xinjiang University \\ Urumqi, Xinjiang 830008, China \\ mx10116@163.com
}

\begin{abstract}
The generalized culture refers to the creation of all human beings, is a symbol of human civilization. The modern culture rooted in the modern industrial civilization is a powerful weapon against the extreme thoughts of religion, and it is the spiritual bond of different nationalities. Modern culture originated in the urbanization of urban areas, and gradually radiation to the vast agricultural and pastoral areas. Xinjiang grassroots areas, especially farming and pastoral areas, is the main battlefield against religious extremes. In the Xinjiang grassroots to promote modern culture, has a pivotal strategic significance. Based on the investigation and analysis of the current situation of modern grassroots propaganda in Xinjiang, this paper points out the shortcomings of the conceptual definition, transmission, top design, acceptability, type of form and nature of operation, and then puts forward the corresponding of the six measures to really achieve the goal that "to take the lead in modern culture, to promote the integration of national psychological exchange", to achieve long-term stability and social development to contribute.
\end{abstract}

Keywords-Modern

Culture;

Communication; Countermeasures

\section{INTRODUCTION}

"Modern culture as a guide" that Regional Party Committee putting forward is a real strategic position of the strategic approach, and it has a fundamental or decisive significance to achieve long-term stability and leap-forward development of the two historical tasks in Xinjiang. The reason why this is said, because the modern culture is a symbol of modern civilization, and a scientific weapon which the human society against to the backward, ignorant, advocate democracy. And then it is the spirit link of different nationals each other exchanged too. In recent years, all levels of Xinjiang has made some achievements in the modern culture as the lead, to promote the integration of national psychological exchanged, and initially curbed the spread of religious extremes, made the preaching activities of "Anti-violence, Attention to the rule of law and order" obtain the results.

National Social Science Fund major project "Islamic extremism on the impact of Xinjiang and to extreme research”(15ZDA035);Autonomous regions of ordinary colleges and universities humanities and social science key research base "Xinjiang national literature research base" key project Based on Islamic literature philosophical extreme ideology research(010515A01).

\section{Problem in the Propagation OF Modern CUlture}

Because of the lack of understanding of modern culture and its way of transmission, there are still some shortcomings in Xinjiang, especially some grassroots units in strengthening the modern culture to lead and play its role. Because the northern region in the economic, cultural and social development is leading the southern region, so its existence in the modern culture of the problem, it must exist in the southern region. For this reason, we selected 12 grassroots townships (including 5 autonomous townships and 4 natural villages)of Shawan, Manasi and Hutubi 3 counties on the northern slope of the Tianshan Mountains as the survey objects, access to information, seminars and other forms, to find its existence in the modern culture of the problem.

\section{A. Definition of the Connotation of Modern Culture is Not Clear}

Modern culture which refers to the people adapted to the requirements of modern culture is to achieve the modern transformation of culture and the construction of modern values, the formation of modern identity, publicity and modern spirit and then build a common belief in the culture. [1]Its main content is: the modern knowledge, modern science and technology, modern production methods, modern lifestyles, modern way of thinking and modern thinking, modern spirit, modern faith, modern religious ideas, modern art. They together cast a modern value, and all this to shape the modern people, in turn, for the modern service. The core and ultimate goal of modern culture is to shape the modern people, through the formation of modern knowledge and accomplishment, to refute the law of the development of human history of the fallacies.

The main core of modern culture is consistent and coupling with the socialist core value system and the socialist value system. The modern transformation of modern society, modern identity, modern spirit and culture of modern transformation is the core of modern culture and its construction and the main task. Acceptance, cognition and identity of modern culture means the acceptance and recognition of socialist values, which is the cornerstone of the socialist development. [2] 
However, at the grassroots level and the cultural station, the traditional culture and characteristic culture of each nation are often carried forward as modern culture, blurred the difference between modern culture and traditional culture, and restricted the leading role of modern culture. For example, in Shawan County Lao Sha Wan Town Cultural Station, they set up a special song in Xinjiang opera troupe. In fact, although the song is a local opera in Xinjiang, but its main reflection is the Qing Dynasty Shanxi and Gansu immigrants spiritual and cultural appearance, away from the modern Xinjiang culture far, more difficult for other native residents accepted. For example, in Shawan County Liu Maowan cultural station, there are traditional Kazakh embroidery products. These embroidery as a national identity is understandable, but if it is regarded as Kazakh modern culture, it will produce misleading effect, that its modern culture, but so. Cultural sector so, the general residents of the cognitive situation is even more worrying. Take our modern cultural awareness questionnaire as a resident of the town of Harmony Homestead in Manas County as shown in table I.

TABLE I. Questionnaire OF COGNITIVE StATUS OF MODERN CULTURE

\begin{tabular}{|c|c|c|c|c|c|}
\hline & $\begin{array}{c}\text { Fully } \\
\text { Understood }\end{array}$ & $\begin{array}{c}\text { Do Not Fully } \\
\text { Understand }\end{array}$ & $\begin{array}{c}\text { Basic } \\
\text { Understand }\end{array}$ & $\begin{array}{c}\text { Basic Do Not } \\
\text { Understand }\end{array}$ & $\begin{array}{c}\text { Completely } \\
\text { Do Not } \\
\text { Understand }\end{array}$ \\
\hline $\begin{array}{c}\text { Number Of } \\
\text { People(100 } \\
\text { Persons) }\end{array}$ & 6 & 10 & 14 & 32 & 38 \\
\hline Percentage & $6 \%$ & $10 \%$ & $14 \%$ & $32 \%$ & $38 \%$ \\
\hline
\end{tabular}

\section{B. On the Way of Modern Culture, Fuzzy Understanding of} the Way

Cultural communication refers to the process by which human culture propagates outwardly from its original origin or propagates from one social group to another. [3]It can be divided into direct communication(explicit transmission)and indirect transmission(implicit communication), the former usually by the culture of people through diplomatic missions, caravans, military and other means to directly spread a certain spiritual or material aspects cultural content, such as the new science and technology; the latter shows a more complex cultural diffusion ability, mainly refers to a social group borrowed outside the cultural characteristics of the principle of civilization to create a stimulus activity.

In direct communication, the media is mainly human migration and mobility; especially in the crowd migration is more important. In addition, trade, tourism and other forms of mobility, but also an important medium for the dissemination of culture. In the contemporary era, due to the development of means of communication and communication technology, the media of cultural communication is not necessarily dependent on the movement and movement of people. The media are mostly media, radio, network, magazines, newspapers, books, public opinion and other media. In indirect communication, the cultural elite in this social group is the most important medium. In real life, they usually use hard to learn modern civilization, efforts to improve their own quality to spread the modern culture. In contrast, the former label color is obvious, vulnerable to conflict; and the latter is moisturizing silence, it is easy to be accepted. Especially for a strong heroic complex of
Xinjiang ethnic minorities, the national elite of the leading and pointing role is self-evident.

However, due to various reasons, especially the long-term "Heavy collective light individual" inertia thinking, our district grassroots cultural propaganda departments pay special attention to radio, television, newspapers, networks, slogans, publicity and other direct publicity, ignoring the use of cultural elite or social elite indirect communication. This kind of single communication channel is mainly constructed on the basis of the county cultural bureau-radio station, television station, cultural station-town (street) cultural station, radio station, completely rely on administrative power, not with social forces, more difficult for the system of the masses accepted, especially those who need to be corrected through the community. This group is often the social stability and national security risks, but also the focus of the three forces penetrate the object. In some of the religious atmosphere of the rural areas of Manas County, we found that it did not understand the modern culture through government propaganda, but rather that some of the advanced cultures were given by heaven, according to some doctrines or other informal channels the gift of the believer. To the county six village town 1 village Muslim faithful access to modern culture as an example, the results as shown in Fig. 1.

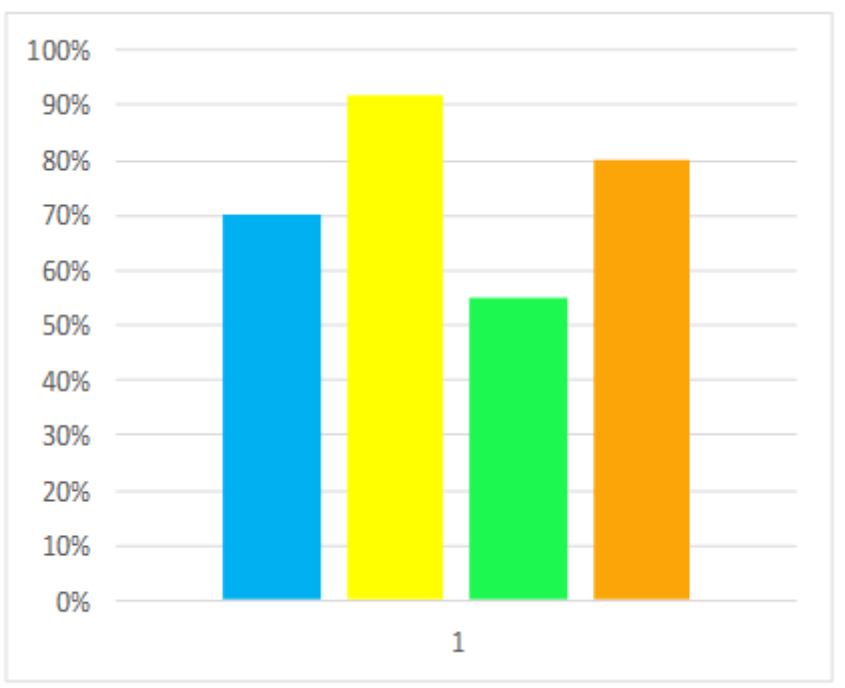

Fig. 1. Survey of modern cultural access channels

(Note: Blue said that by word of mouth, that is, through other believers, about $70 \%$. Yellow represents religious propaganda, that is, through the "Koran" or the Sunnah, about 92\%. Green that government propaganda, that is, through radio, television, newspapers, slogans, accounting for about $55 \%$

Orange that religious sites, imam and other clerics, accounting for about $80 \%$.)

Instruction for the survey: selected ordinary Muslim believers 50 people, men, mainly concentrated in the age of 3050 years old, mainly to the primary level of education, not including fanatical believers. On the Full Coverage of Modern Culture lack of Macro Design.

The essence of culture lies in man himself, the essence of modernity lies in the modern quality of the people themselves, the essence of modern culture is that people with modern cultural quality itself. That is, the scale of people to measure people, develop people, perfect people is the pursuit of modern culture. Through the spread of modern culture, emphasizing the 
understanding of communication, through tolerance, dialogue, error correction, action and other ways to achieve unity of knowledge and practice, rational thinking and scientific spirit of unity, to achieve the goal of happiness for all. Therefore, the object of modern culture should be the community of all citizens, that is, through modern culture to transform the community of all citizens of the subjective world.

For Xinjiang, the modern culture is to improve the social citizens as a platform, and then vigorously carry forward the "patriotic love, unity and dedication, hard work and mutual assistance, open and enterprising” spirit of Xinjiang to promote the great development and prosperity of Xinjiang culture. [4]In the Xinjiang culture from the traditional to the modern at the same time, we can enhance the cohesion of grassroots people in the hearts of the people to build against the extreme religious thought penetration of the dam. Extreme thought of religion in some rural areas, the main reason is still the local still in a more backward, more ignorant social atmosphere. When this lagging culture is in conflict with the culture of advanced culture, the social groups in the former inevitably appear to be incompatible, and thus make radical or irrational reactions under certain instinctive instigation. In fact, this is also a source of terrorism and religious extremism.

Due to economic factors and social control factors, in the spread of modern culture, the real benefit of the scope is not wide. On the cultural level of the township level (Shawan County Lao Sha Wan Town Cultural Station), for example, the modern culture of the audience mainly presents three characteristics: mainly in the elderly, self-sufficiency to the economic income to the system within the group mainly. The specific audience is shown in table II:

TABLE II. LIST OF MODERN CULTURAL AUDIENCES

\begin{tabular}{|c|c|c|c|c|c|}
\hline $\begin{array}{c}\text { characteristics } \\
\text { Age }\end{array}$ & $\begin{array}{l}\text { Economic income } \\
\text { Self-sufficiency }\end{array}$ & $\begin{array}{l}\text { Economic income } \\
\text { Non-self-supporting }\end{array}$ & $\begin{array}{l}\text { system Internal } \\
\text { work }\end{array}$ & $\begin{array}{l}\text { outside } \\
\text { work }\end{array}$ & audience \\
\hline \multirow{4}{*}{$\begin{array}{l}14 \text { years old-35 years } \\
\text { old (adolescents, total } \\
20 \text { people, +yes, - no) }\end{array}$} & + & - & + & - & 5 \\
\hline & - & + & - & + & 6 \\
\hline & + & - & - & + & 5 \\
\hline & - & + & + & - & 4 \\
\hline \multirow{4}{*}{$\begin{array}{c}\text { 35-55 years old(middle } \\
\text { age, total } 20 \text { people, }+ \\
\text { yes, -no) }\end{array}$} & + & - & + & - & 8 \\
\hline & - & + & - & + & 3 \\
\hline & + & - & - & + & 5 \\
\hline & - & + & + & - & 4 \\
\hline \multirow{4}{*}{$\begin{array}{c}55 \text { years old to } 75 \text { years } \\
\text { old (old age, total } 20 \\
\text { people, +yes, -no) }\end{array}$} & + & - & + & - & 10 \\
\hline & - & + & - & + & 3 \\
\hline & + & - & - & + & 3 \\
\hline & - & + & + & - & 4 \\
\hline
\end{tabular}

In addition, according to our sampling statistics on the residents of Shidaohezi in Shawan County(sample size is 100), the audience who can accept the culture of modern culture in the township is only $30 \%$ of the members of the whole society. It can be seen that the majority of young adults, low income, the system outside, the social vulnerable groups have not been the direct impact of modern culture. Although there are many reasons for this situation, such as this group is not free time, life pressure, not interested in the traditional way of transmission and so on. But the cultural propaganda department at all levels lack of awareness of the audience of modern culture, the lack of modern culture, full coverage of the macro-design is its inherent deficiencies.

\section{On the Acceptance of Modern Culture, Awareness, Recognition is Not High}

In the main core of modern culture and the socialist core value system and the socialist system of values, there are consistency and coupling. The modern transformation of modern society, modern identity, modern spirit and culture of modern transformation are the core of modern culture and its construction and the main task. [5]Modern values are the basis of modern culture, and their values include: "benevolence, prosperity, justice, civilization, harmony, autonomy”. Modernity is the driving force of modern culture, that is, the spirit of "patriotism, unity, diligence, mutual help, openness and enterprising" is our modern spirit and style, which is the main aspect of modern identity.

Acceptance, cognition and identity of modern culture mean acceptance and recognition of socialist values. It is the cornerstone and motive force for the continuous development of socialism. [6] This acceptance, recognition and recognition also exist in the degree of difference, of which the highest degree is the main builder of the cause of socialism. The lower degree, it is the auxiliary, is the object of the united front. Do not accept, do not recognize and deny, it is the object of socialism dictatorship. These three groups should be "pyramid" type, that is: the highest number of the largest, number of people who do not accept the least.

In the grassroots farming and pastoral areas of Xinjiang, the original social organization, the values and the outlook on life have not been well inherited in some of the young people, because the original forms of social organization have been broken up and the new forms of social organization have not yet been fully established. The in particular, in recent years, in the foreign anti-China forces, "three shares" forces and other domestic and some "known”, “ national elite” and so on, some of the agriculture and pastoral areas of youth "three view" is more chaotic. Coupled with the dogmatic, direct modern way of modern culture, many people recognize and accept more reflected in the surface, at a lower level. Some people even 
refused to accept the modern culture. This situation is not only prevalent in the "dangerous elements" of the community, but also in some groups where the political stance is not firm and the political attitude is not correct. A case study of "three concepts” of rural youth in Hutao County, as shown in Fig. 2:

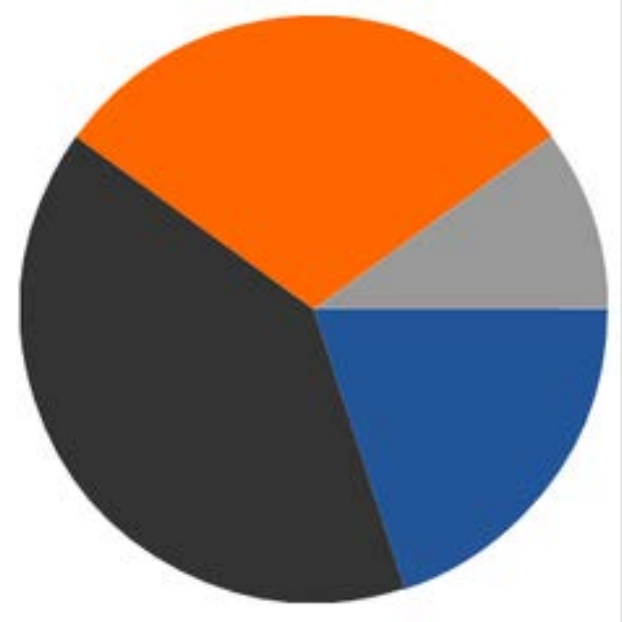

Fig. 2. Cognition of “Three Outlooks” of Teenagers

Instruction for the survey: among the 30 young people were selected, including 18 males and 12 females, mainly in high school education, mainly using the questionnaire and field observation method.

Orange that fully recognized, 12 people, accounting for $40 \%$.

Blue that identity, 6 people, accounting for $20 \%$.

Gray that basic recognition, 2 people, accounting for 6.7\%.

Blue and gray indicate a lower level of cognition and acceptance.

Black does not agree or basically do not agree, 10 people, accounting for $33.3 \%$.

\section{Cultural Products Supply Chain Serious Imbalance, the Form is More Traditional}

The so-called culture, that is, all created by mankind, both the material form, but also the non-material form. [7]Cultural products is the product of cultural activities, human transformation of the objective world and the result of the subjective world, it is mainly divided into material and nonmaterial cultural products. Modern cultural products mainly refer to the industrial society, the human creation of science and technology, lifestyle and ideas. [8]Modern technology products are: cars, trains, aircraft, satellites, computers and artificial intelligence, mechanical and electrical integration technology, etc. .;modern lifestyle are: travel pay attention to speed, fast pace of work, life without law, eat fast food, overnight life, participation in challenging activities and so on; modern ideas are: reform and opening up consciousness, competition consciousness, efficiency consciousness, innovation consciousness, democracy and legal consciousness and so on.

In the report of the 13th Party Congress, it is pointed out that in the primary stage of socialism; the most important contradiction is the contradiction between the growing material and cultural needs of the people and the backward social productive forces. In other words, while vigorously developing social productive forces, it is necessary to increase the supply of cultural products to meet the spiritual needs of the people. That is to continue to meet the socialist citizens of modern ethics, social energy and justice is fair, the spread of modern ideas of literature and art of the pursuit. If you can't meet the cultural needs of the people, will inevitably lead to the loss of social morality, good and evil regardless of the spirit of decadence.

To this end, we must create a good cultural product, and sent to the people. In the supply of modern cultural products, the state-province-municipality is the main body, grass-roots and agricultural and pastoral areas are at the end of supply. Xinjiang, for example, the supply of modern cultural products market is more adequate large and medium cities, such as Urumqi, Korla, Karamay, Shihezi and so on. While the supply is not enough in the grassroots and farming areas. Due to the low level of urbanization in Xinjiang, a considerable number of consumers are living in grassroots and farming areas. As the end of the cultural product supply chain, they accept cultural products, more passive acceptance, can’t fully participate. In particular, the modern cultural products born in large and medium-sized cities are difficult to accept for the latter because they are incompatible with the social productivity of grassroots and pastoral areas. Taking our survey of the acceptance of modern cultural products by the residents of Jindouhe Township in Shawan County as an example, as shown in table III:

TABle III. List of Audience Status of Modern Cultural Products

\begin{tabular}{|c|c|c|c|c|c|}
\hline $\mathrm{F}_{\text {education }}^{\text {Age }}$ & $\begin{array}{c}\text { Primary school } \\
\text { (elementary school) }\end{array}$ & $\begin{array}{c}\text { Secondary(second } \\
\text { ary) }\end{array}$ & Higher(college) & Number & $\begin{array}{l}\text { Accepted of } \\
\text { people }\end{array}$ \\
\hline \multirow{3}{*}{$\begin{array}{c}\text { 20-30 years old(+yes, - } \\
\text { deny) }\end{array}$} & + & - & - & 10 & 5 \\
\hline & - & + & - & 10 & 7 \\
\hline & - & - & + & 10 & 8 \\
\hline \multirow{3}{*}{$\begin{array}{l}\text { 30-40 years old(+yes, - } \\
\text { deny) }\end{array}$} & + & - & - & 10 & 3 \\
\hline & - & + & - & 10 & 5 \\
\hline & - & - & + & 10 & 8 \\
\hline \multirow{3}{*}{$\begin{array}{l}40-50 \text { years old (+yes, - } \\
\text { deny) }\end{array}$} & + & - & - & 10 & 3 \\
\hline & - & + & - & 10 & 4 \\
\hline & - & - & + & 6 & 3 \\
\hline
\end{tabular}




\begin{tabular}{|c|c|c|c|c|c|}
\hline \multicolumn{6}{|c|}{ Cont. to TABLE III } \\
\hline \multirow{3}{*}{$\begin{array}{c}\text { 50-60 years old (+yes, - } \\
\text { deny) }\end{array}$} & + & - & - & 10 & 3 \\
\hline & - & + & - & 8 & 3 \\
\hline & - & - & + & 5 & 2 \\
\hline \multirow{3}{*}{$\begin{array}{c}\text { 60-70 years old (+yes, - } \\
\text { deny) }\end{array}$} & + & - & - & 10 & 2 \\
\hline & - & + & - & 5 & 3 \\
\hline & - & - & + & 5 & 2 \\
\hline
\end{tabular}

It can be seen, different backgrounds, different age residents of modern cultural products are not the same degree of fitness. Of which 20-40 years old, moderate education and above the higher fitness, 40-70 years old, primary school education level of fitness is low. In the grassroots and farming areas, most of the left-behind population is between $40-70$ years old, and the education level is not high. In addition, more cultural products are based on the film, television, music, dance and other art forms, the idea of the concept of more straightforward, it is difficult to penetrate the hearts of the masses, play a subtle role.

\section{E. Cultural Industry Development in a Single Form, the Nature of Outstanding Business}

Cultural industry is an important carrier for the prosperity and development of socialist culture under the condition of market economy. It is an important way to meet the needs of the masses, multi-level and multi-faceted spiritual culture. It is also an important point to promote economic restructuring and change the mode of economic development. [9]From this level to understand the words, the modern cultural industry is the production of intangible cultural products, aimed at meeting the spiritual needs of the people. Cultural industry is the sum of cultural resources + social productive forces + social production methods that is, with advanced productive forces or production methods to develop and use existing cultural resources, to create new cultural products. It mainly includes news services, publishing and distribution, radio and television, arts and culture or leisure services, network culture or games, stationery and equipment, the production of cultural products, related cultural products sales.

As an industry, cultural industries to follow the laws of the market, that is: only meet the needs of customers of products, to have the market. But the cultural industry has a certain degree of particularity, to serve the state power and social stability. This is because if the cultural industry abandons its political nature, focusing only on its commercial nature, will inevitably lead to the ideological field of diversity, harm the core values of socialism, and shake the socialist regime under the rule of the foundation. The duality of cultural industry is the main characteristic and principle of cultural development in our country, and it is the basic manifestation of culture to meet the needs of socialist market economy. [10]

This feature requires the cultural industry must walk on two legs, not biased, it is necessary to pay attention to the market, but also pay attention to politics. However, from the perspective of the cultural industry at the grassroots level in our region, the cultural resources and the social productive forces are the same. The cultural resources are only the basis and platform for the development of social productive forces. The so-called "cultural stage, economic singing" and market characteristics are highlighted. Shawan County, the representative of the cultural industry -"Market Food Festival", for example, the local food market Chicken display, the purpose is to promote the county poultry and pepper sales, for the broader market reflects the fusion of cultural awareness of chicken less mention. This emphasis on the market economy, dilute the political service point of view long, will inevitably damage the socialist system. The following is the Shawan County market food culture specific arrangements, as shown in table IV:

TABle IV. Cultural Festival SChedule

\begin{tabular}{|c|l|l|l|}
\hline TIME & \multicolumn{1}{|c|}{ NAME } & \multicolumn{1}{c|}{ PLACE } & \multicolumn{1}{c|}{ CONTENT } \\
\hline $\begin{array}{c}\text { 12:00p.m. } \\
\text { August 6 }\end{array}$ & $\begin{array}{l}\text { Opening } \\
\text { ceremony }\end{array}$ & Food plaza & $\begin{array}{l}\text { Fire a solute, leaders' } \\
\text { address and artistic } \\
\text { performance }\end{array}$ \\
\hline $\begin{array}{c}\text { 13:00p.m. } \\
\text { August 6 }\end{array}$ & $\begin{array}{l}\text { Taste the first } \\
\text { dishes in the } \\
\text { world }\end{array}$ & Food plaza & $\begin{array}{l}\text { Taste the Saute Spicy } \\
\text { Chicken }\end{array}$ \\
\hline August 6-8 & $\begin{array}{l}\text { Exhibition of } \\
\text { local products }\end{array}$ & $\begin{array}{l}\text { Mall of } \\
\text { Taoyuan road }\end{array}$ & $\begin{array}{l}\text { Sale the local } \\
\text { characteristic } \\
\text { agricultural } \\
\text { byproducts }\end{array}$ \\
\hline August 6-8 & $\begin{array}{l}\text { Exhibition of } \\
\text { touism products }\end{array}$ & Food plaza & $\begin{array}{l}\text { Sale the tourism } \\
\text { products, stone and } \\
\text { jade }\end{array}$ \\
\hline August 6-8 & $\begin{array}{l}\text { Exhibition of } \\
\text { beautiful } \\
\text { housing }\end{array}$ & Food plaza & $\begin{array}{l}\text { House sales, } \\
\text { decoration and design }\end{array}$ \\
\hline August 6-8 & Visit the garden & Forest park & $\begin{array}{l}\text { Visit the garden and } \\
\text { participate in the } \\
\text { entertainment activity }\end{array}$ \\
\hline August 6-8 & Folk concert & $\begin{array}{l}\text { Cultural } \\
\text { palace }\end{array}$ & $\begin{array}{l}\text { Appreciate folk songs } \\
\text { and dance coupled } \\
\text { with instrument } \\
\text { performance }\end{array}$ \\
\hline August 6-8 & $\begin{array}{l}\text { Closing } \\
\text { ceremony }\end{array}$ & $\begin{array}{l}\text { Firework show and } \\
\text { tasting sancks }\end{array}$ \\
\hline
\end{tabular}

\section{SOlutions to the PRoBlem ANd BAsis}

Culture known as the social internal combustion engine, is a soft power. Modern culture as a spiritual strength, social development and personal growth has a profound impact on people's practical activities, awareness activities and ways of thinking are inseparable from the role of culture. [11]With modern culture as the lead, to promote the integration of national psychological exchange is the trend of the development of modern culture in Xinjiang, is the reality of long-term stability needs. For the problems in the development of modern culture in Xinjiang, we think that the following measures can be taken to correct:

\section{A. Establish the Concept of Modern Culture, Promote the Transfer of Traditional Culture to Modern Culture}

For the traditional culture, is the need to inherit. But modern culture is a country in the development process, people 
in today's lifestyle, science and technology level formed under a new ideas, moral standards, and codes of conduct and so on. Its share in a national culture, marking the level of development of this nation. [12]In order to achieve a new stage of social production in Xinjiang, we must actively guide and promote the rapid development of traditional culture to modern culture.

Especially in the Xinjiang "three" superposition of the critical period, this shift has a more important practical significance. As we all know, due to the long-term tendency of secularization of Islam, Xinjiang's religious tradition of Islam contains a large number of religious factors. Some of these religious factors are positive, some are negative, extreme. Therefore, to play a guiding role of modern culture, you can to a certain extent, the negative impact of the elimination of religious factors.

\section{B. Strengthen the Town in the Core of Modern Cultural} Transmission, Increase the Radiation in Remote Farming Areas

The city is not only the place of cultural production, the center of culture, but also the spread of culture. It can be said that in any historical period, the city is the era of "modern culture" cradle, incubator, production base, radiation center, of course, it is "modern culture" to enjoy. Therefore, the city as a product of modern culture and the birthplace of its status is not man-made, but the inevitable development of culture. [13]

Due to the special geographical conditions of Xinjiang, one of the few cities on the majority of agricultural and pastoral areas of radiation and impact is more prominent. These cities have a modern mode of production and communication channels, as well as modern lifestyles and ways of thinking; it is the natural culture of the natural communication center. If we do not strengthen the city's role in the spread of modern culture, then the agricultural and pastoral areas can only be more closed, more backward, more easily reduced to the religious forces of the soil.

\section{Take Rewards and Punish Measures, Broaden the Audience of Modern Culture}

For the face of modern culture, it is imperative to convert unaffected groups into audiences. In view of this group of ideological consciousness is not high, the lower the level of economic reality, you can take a combination of incentives and punishment in the form, urging them to accept the impact of modern culture. At the same time, the original audience, you can take a more flexible form, with a variety of content to stabilize the audience psychology and audience.

The acceptance of modern culture can't let the social groups conscious and spontaneous. This is because the modern culture to bring the audience is more spiritual pleasure, spiritual enjoyment, rather than simply eats and eat warm, to maintain life. With the passive acceptance, in the basic life to a certain degree of protection, the social groups will gradually change their attitude; take the initiative to accept the modern culture. It must be pointed out that this group is also the object of both sides.

\section{Pay Attention to the Seclusion of Modern Culture, Enhance the Audience Awareness and Recognition}

With the development of society and the enhancement of audience self-consciousness, the use of direct, explicit means to spread the modern culture, its effect is decreasing. Therefore, only to strengthen the construction of cultural soft power, the use of implicit means of communication, in order to increase the audience awareness of the modern culture and identity. [14]Implicit means of transmission is essentially through the use of various cultural products, through subtle forms, the socialist values into the depths of the audience.

In addition, we must pay attention to the use of modern means of communication, especially in the form of new media, such as network, SMS, WeChat, Twitter, QQ, blog, paste it and other use. With the audience can choose to spread the channel, since the media has become an important way. [15]Therefore, to strengthen the management and guidance from the media, so that it is an indispensable means to promote positive energy. In addition, it is necessary to make clear the audience's awareness and recognition as the goal and task of modern cultural communication work, and promote the healthy development of modern culture.

\section{E. Meet the Needs of the Masses as the Guide; Improve the Supply of Cultural Products}

In the production and processing of cultural products, it is necessary to take into account the needs of consumers, but also take into account the needs of the cause of socialism. In the current cultural products, in line with the needs of urban residents of cultural products is not less, but for the grassroots and rural areas of the needs of the masses are few. Therefore, it is imperative to combine the grassroots and the reality of the pastoral areas, to produce the masses loved to reflect the socialist values of cultural products.

At the same time, in the production of cultural products, but also play the grassroots and the role of the masses of farming and pastoral areas, to encourage their active participation, especially the cultural and human participation. These cultural people from the grassroots level, with a strong life experience, the creation of cultural products close to life, will be able to produce a greater response. At the same time, due to the participation of grassroots people, and thus can form a complete supply chain. Entire supply chain participants, not only the producers of cultural products, but also the consumers and beneficiaries of cultural products.

\section{F. Increase Policy and Financial Tilt Efforts; Restore the Cultural Industry, the Nature of Public Welfare}

Cultural industry in essence, is to meet the cultural needs of the people of the emerging industries. [16]In Xinjiang, the economy is not yet developed, living standards are relatively backward today, relying on the cultural industry for the operators to quickly profit, and to solve the surplus labor force for the region to increase taxes is unrealistic. From the perspective of political politics, the cultural industry is to carry forward the socialist values, unity and cohesion of social citizens for the purpose of the public welfare industry. 
Therefore, governments at all levels in Xinjiang should formulate policies and tax concessions, cultivate and develop cultural industries close to local social life, and constantly meet the spiritual needs of the masses. Through the policy tilt, but also in a certain period of time, as far as possible to restore the cultural industry's public welfare. Because only take the road of public welfare in order to attract the masses, take the initiative to accept the modern culture, so as to promote the psychological blend of all ethnic groups.

\section{CONCLUSION}

American scholar Samuel Huntington in the "The Clash of Civilization?" article that: culture and civilization will be separated at the same time, cultural similarities will bring people together, and promote the mutual trust and cooperation, which helps to weaken or eliminate barriers. Therefore, we have reason to believe that the modern culture of communication as a promoter, and vigorously promote the popularization of modern culture at the grassroots level, you can unite the people of all ethnic groups in Xinjiang, together to build and resist the Great Wall of steel against the extreme ideas of religion

\section{REFERENCES}

[1] Niu Ruji. On the "modern culture" theory and practice [J] Journal of Xinjiang Normal University, 2011(3):1-14.

[2] Shen Xiulan. With modern culture as the guide, strengthen the "four identity" [J] Journal of Xinjiang Vocational University, 2012(1):1-3.
[3] Guo Qingguang. Communication Course [M]. Beijing: Renmin University of China Press, 2011:12.

[4] Shen Nanqiao. Modern culture and social development in Xinjiang [J]. Commercial Culture, 2013(4):132-133.

[5] Niu Ruji. On the "modern culture" theory and practice [J] Journal of Xinjiang Normal University, 2011(3):1-14.

[6] Shen Xiulan. With modern culture as the guide, strengthen the "four identity" [J] Journal of Xinjiang Vocational University, 2012(1):1-3.

[7] Han Zechun. China's modern cultural development program[M].Beijing: China Social Science Press, 2010:6.

[8] Han Weibiao. Modern cultural theory guide [M]. Wuhan: Wuhan University Press, 2015:10.

[9] Yang Likun. Vigorously promote the cultural cause and cultural industry than the wing fly [J] Political Work, 2010(4):12-13.

[10] Han Yongjin. China's cultural industry in the past decade the development of the road back [J] Journal of Huazhong Normal University, 2011 (1):85-90.

[11] Du Huimin. On "to modern culture as a guide" [J] Economic Research Guide, 2011(6):232-233.

[12] Li Zhimin. Modern culture discussion [M].Beijing: People's Publishing House, 2015:128.

[13] Li Ying. Seventeenth session of the Fifth Plenary Session of the seven key words [J] Today Guizhou, 2011(12):12-14.

[14] Li Ruonan. Autonomous Region People's Congress Standing Committee of the party group to learn and practice the general secretary of $\mathrm{Xi}$ Jinping seven important speech spirit [J] Xinjiang People's Congress, 2016(8):6-10.

[15] Xu Jing. Communication theory [M]. Beijing: Tsinghua University Press, 2013:137.

[16] Zhu Wei. Cultural attributes and cultural industry practice philosophy analysis [J] Journal of Sichuan Correspondence College, 2010(5):18-24. 